Internal networking and innovation ambidexterity: The mediating role of knowledge management processes in university research

Paper published in

\title{
European Management Journal
}

Full citation to this publication:

D Cabeza-Pullés, V Fernández-Pérez, MI Roldán-Bravo (2020). Internal networking and innovation ambidexterity: The mediating role of knowledge management processes in university research. European Management Journal, 38 (3), 450-461.

https://doi.org/10.1016/j.emj.2019.12.008

Thank you for your interest in this publication 


\title{
Internal networking and innovation ambidexterity: The mediating role of knowledge management processes in university research
}

\begin{abstract}
This article focuses on public organizations to contribute to research on knowledge management processes, a field that until recently has focused primarily on private entities. Specifically, we analyse the mediating role of knowledge transfer and knowledge absorption in the relationship between the internal networking created in university research groups and innovation ambidexterity. Based on six hypotheses, the conceptual model is tested through a structural equations model with mediation effects. The data analysed come from 249 directors of Spanish public university research groups. The results show that the internal networking formed in university research groups has a positive and significant relationship to knowledge transfer and knowledge absorption, but we obtain different results for the relationship between knowledge transfer and knowledge absorption in the presence of innovation ambidexterity. Only knowledge absorption has a positive and significant influence on innovation ambidexterity. The most interesting results involve the mediating role of knowledge absorption in the relationship between internal networking and innovation ambidexterity. These results support the conclusion that directors of university research groups should promote development of knowledge absorption processes in order to stimulate innovation ambidexterity and thus to achieve ambidextrous innovative performance.
\end{abstract}

Keywords: Internal networking; innovation ambidexterity, knowledge transfer; knowledge absorption; university research. 


\section{Introduction}

Nowadays, public universities must confront a great variety of challenges, among others, globalization of competition, decrease in governmental financial aid, changing demands from society, and creation and capture of the benefits reaped from innovation ambidexterity (IA) organizational activities devoted to pursuing exploitation and exploration simultaneously (He \& Wong, 2004; Smith \& Tushman, 2005; Heavey \& Simsek, 2014) - (García-Sánchez et al., 2019; De Saá-Pérez et al., 2017).

To face these challenges, to generally and jointly pursue both explorative and exploitative innovations, and to be ambidextrous, public universities must expand their activities related to knowledge management (Cordero \& Ferreira, 2019; García-Sánchez et al., 2019). Public universities are expected to create and transfer knowledge because they handle the main scientific and technological innovations that drive advances in society. It is important to note that university research groups play a crucial role in the academic context. Knowledge is increasingly produced not through the work of individual researchers but in the joint work of members of the group to which the individual belongs and the integration of individuals' knowledge into the framework of the research projects in which they participate (Cabeza et al., 2017; Hinnant et al., 2012; Stvilia et al., 2011). It is thus the responsibility of the research group to manage its knowledge well to generate and benefit from IA (Lin et al., 2013). In general terms, the ability to transfer and absorb knowledge gained becomes critical (Powell, 1998) to developing new organizational abilities, among these, IA (Enkel et al., 2017). Scholarly efforts to resolve the ambidexterity question and the role played by knowledge management processes (Wang et al., 2006; Cabeza et al., 2017) have, however, left a gap in our understanding of how to achieve ambidexterity, particularly in public universities (Al Ahbabi et al., 2019). For this reason, we seek to answer the following question: 
How can knowledge management processes (KA and KT) and the internal context of public university research groups (internal networking) lead to innovation ambidexterity?

In this study, we analyse internal networking to approach the internal context of university research groups and propose the mediating role of knowledge management processes-KA and KT - in the relationship between the internal context of university research groups and the creation of IA. Internal networking is defined as the real set of all connections and the frequency of interaction and communication that occur internally within a group of individuals (Mitchell, 1973). Knowledge management — and by extension its processes (KA and KT) — is a driver that research groups can use to generate IA (Lin et al., 2013). As a whole, the main objective of this paper is to analyse the mediating role of KT and KA in the relationship between the internal networking created in public university research groups and IA. As a result, this paper makes several contributions to both literature and practice.

From a theoretical perspective, it first responds to calls in the literature for further analysis of the antecedents of innovation ambidexterity in multifaceted settings-in our case, public universities. Second, it contributes to responding to the need the literature proposes to reduce the discrepancies between theory and practice in interpreting the nature of KA and its relationship to internal organizational processes (Cordero \& Ferreira, 2019), especially in the public sector. We find no studies relating $\mathrm{KA}$ in university research groups to internal networking. The lack of development of this topic supports the thesis that this research field is still emerging. Our hypothesis accepts the challenge of focusing research efforts on demonstrating the relationship between internal networking and KA and its mediating effect in the context of university research groups. Third, although knowledge transfer has received much attention at the theoretical and empirical levels in the literature on the context of private organizations, the field lacks studies of public organizations (Oluikpe, 2012; RingelBickelmaier \& Ringel, 2010; Al Ahbabi et al., 2019). Yet current research argues that the 
structure of public universities seems insufficient to encourage KT (García-Sanchez et al., 2019). This literature stresses the importance of finding mechanisms that enable researchers to become more involved in joint discussions and KT (Han et al., 2014). Our study aims to fill this gap by focusing on study of the KT that occurs in public university research groups, which are characterized as slightly autonomous in their decision-making processes (Ryan \& Hurley, 2007) and knowledge management. Our results show that the mere existence of KT is not sufficient to achieve IA in a research group; among other issues, the group must have a sufficient level of absorptive capacity to achieve exploratory and exploitative innovations.

From a practical perspective, our results can be very useful for public organizations in general, as public universities are organizations whose characteristics differ from those of private firms. The article is divided into six sections. Following this introduction, the second section develops the theoretical framework and hypotheses. The third section describes the research methodology. The fourth presents the data analysis and results of the empirical analysis. Finally, the fifth and sixth sections present, respectively, the discussion and conclusions; and the implications, limitations and lines for future research. 


\section{Theoretical framework and hypotheses}

\subsection{Knowledge management theory applied to university research groups}

Knowledge management processes are defined as fundamental actions that an organization performs to process and manage its knowledge resources (Holsapple \& Joshi, 2000). These processes play an essential role in the framework of knowledge management theory, since they provide information on the main tasks and actions to be performed to manage an organization's knowledge resources efficiently (Al Ahbabi et al., 2019). Knowledge management processes include KT and KA. These processes are significant to study of knowledge management (McAdam \& Reid, 2000) because they provide the organization with the individual's knowledge and transform that individual knowledge into collective knowledge - a process that continues to be a fundamental challenge.

If we consider the university as a firm and apply the concept developed by Nonaka and Takeuchi (1995), knowledge management of university research groups would be the capability to create new knowledge, disseminate it within the group, and incorporate it into all research processes developed. In the context of our study, members of public university research groups work together to pursue and develop knowledge, supported by research projects and activities in which they share material and financial resources. These activities would not be possible without proper management of the knowledge, which enables it to flow among group members with diverse, specialized experience (García-Sanchez et al., 2019). For these groups, knowledge is a form of wealth and one of the most important intangible assets (Cabeza et al., 2013; GarcíaSanchez et al., 2019).

University research groups must therefore have the appropriate internal knowledge management strategies to relate knowledge correctly to all members of the group. Because researchers who compose university research groups perform knowledge management 
activities when they organize and develop research projects, it is necessary to study the internal processes of knowledge management that facilitate collective learning in this context.

\subsection{Knowledge transfer and absorption and internal networking}

KT is defined as the process by which a unit, group, department or division is affected by the experience of others (Argote \& Ingram, 2000), both within a group or department and among departments or different levels in the organizational hierarchy (Bhatt, 2001; Szulanski, 1996). KT requires group members to deliver their knowledge and simultaneously obtain knowledge from the other members to modify and reuse that knowledge (Chen \& Hung, 2010).

In this context, KT is performed within the work group, based on the research on which the members collaborate (García-Sanchez et al., 2019). To achieve KT, internal research networks are formed to foster better communication and closer connections among researchers, as these networks enable easier and more frequent KT (Ming-Chao et al., 2018; García-Sanchez et al., 2019) and prevent researchers from working alone (De Saá-Pérez et al., 2017). These actions encourage KT because researchers who work in internal networks are more sensitive to transferring knowledge due to the constant interaction within the networks (Armbrecht et al., 2001). The literature identifies a barrier to this activity, however, finding difficulties in knowledge management in university research. For example, the widespread culture of working alone does not foster cooperation and exchange. We thus propose the solution of fostering internal networking for university research groups.

Researchers represent a specific type of network worker (Dimitrova et al., 2013; GarcíaSánchez et al., 2017). Being linked to an internal network enables them to feel comfortable (Taylor \& Greve, 2006; Lungeanu \& Contractor, 2015) when they do research. They also obtain benefits from integration and create synergies that encourage shared use of resources (Cabeza et al., 2017; García-Sánchez et al., 2017) and better use of the knowledge (Wu et al., 2009) 
when they are linked to internal networks that foster KT. In other words, internal networking is influential in determining the efficacy of the relationship in attempts to transfer knowledge (Argote \& Ingram, 2000).

Along these lines, the debate over the relationship between internal networking and KT has developed in the literature on the private sector, where many authors recognize its positive influence on KT (Dyer \& Hatch, 2006; Baggio \& Cooper, 2010; Fritsch \& Kauffeld-Monz, 2010). To the extent of our knowledge, only García-Sanchez et al., (2019) have analysed this relationship in the context adopted in our study. These authors show that quality of the relationship among academic researchers encourages exchange of knowledge among them. Shedding light on the debate in the literature, specifically by providing information on the behaviour of these variables in the field of our study, is thus important because internal networking can be a determining factor at university research group level. Research groups tend to build relationships of trust among members who collaborate with each other (Khvatova et al., 2016; García-Sanchez et al., 2019). Interactions among these groups' internal networks constitute an increasingly frequent way to organize work (Chen et al., 2012) and to achieve better use of knowledge, be more effective and perform more creative tasks (Wu et al., 2009) all actions that benefit KT. University research groups must develop effective internal networking, since researchers with similar research interests collaborate and share information and experiences (Orlikowski, 2002; Wei-Li \& Yi-Chih, 2016), and ultimately transfer knowledge.

Thus:

H1: Internal networking is positively related to KT in public university research groups. 
$\mathrm{KA}$ is "a dynamic capability pertaining to knowledge creation and utilization that enhances ability to gain and sustain a competitive advantage" (Zahra \& George, 2002, p. 185). KA is defined as a set of organizational routines and strategic processes through which knowledge is acquired, assimilated, transformed and applied in order to create a dynamic capability (Zahra $\&$ George, 2002, p. 2). KA has become one of the most important constructs in recent decades, due to the importance of recognizing the value of new knowledge, as well as the capability to assimilate and use new knowledge to develop improvements (Cohen \& Levinthal, 1990; Cordero \& Ferreira, 2019).

Note that the KA literature generally analyses external KA through the establishment of external cooperation networks (Cross \& Cummings, 2004; Cohen \& Levinthal, 1990; Tushman, 1977; Lowik et al., 2016).

Mechanisms for social integration, understood in our analysis as internal networking, are crucial to understanding the processes of KA (Lowik et al., 2016).

The internal networks of public university research groups are constituted of highly qualified personnel who also usually have similar specialized knowledge, encouraging ease of absorption (Kaplan \& Tripsas, 2008) and communication through the use of common languages and mental schemas (Cohen \& Levinthal, 1990). Since KA includes interpretation and understanding of the information obtained from internal sources (Ebers \& Maurer, 2014; Szulanski, 1996; SolísMolina et al., 2018; Cordero \& Ferreira, 2019), having trained, prepared researchers is a key variable (Arbussà \& Coenders, 2007; Enkel \& Heil, 2014) in the absorption process in internal networking. Efficiency in KA processes is explained not only by the group's internal abilities and qualifications, however, but also by the cognitive proximity of its members - in terms of cultural values and technical capabilities, as well as the solidity or strength of the relationship maintained throughout the knowledge exchange process (García-Sanchez et al., 2019). Since the person-to-person interactions inherent in the internal network engender trust and thus play 
an important role in this process (Block, 2013; García-Sanchez et al., 2019), internal networking in public university research groups encourages connectivity among researchers. Connectivity favours communication and knowledge exchange, as well as recovery and improvement of the group's knowledge (Hentonnen et al., 2014), and ultimately KA (Jansen et al., 2005; Todorova \& Durisin, 2007).

Internal networking involves heterogeneity of contacts among the researchers who compose the network. The more diverse these contacts, the more likely it is that researchers know who knows what (Lowik et al., 2016), and the greater the probability of finding relevant information, which can contribute to effective problem solving (Cross \& Cummings, 2004), greater development of absorption capacity, and ultimately better development of research activities. Internal networks in university research groups can also affect researchers' performance (Cross \& Cummings, 2004) through KA by providing the group with knowledge integration.

In sum, researchers who work on internal networking will be oriented to problem solving, professional development and continuous learning (Lazzarotti et al., 2017), which in turn are useful for KA.

Thus:

$H 2$ : Internal networking is positively related to KA in public university research groups.

\subsection{Knowledge transfer and absorption and IA}

The relationship of KT and KA to innovation has been studied in the literature (Farzin et al., 2014), but its influence on IA has received little attention. Even now, the field continues to assert the need for more information on this issue, since knowledge is the key to combining innovative activities (Ju et al., 2006; Wehn \& Montalvo, 2018) and debate in the field remains open as to what facilitates ambidextrous innovative performance. 
Ambidexterity is the capability of performing basic functions while simultaneously developing other functions different from the basic ones in order to improve performance (Cao et al., 2009; Raisch et al., 2009; Sengupta \& Ray, 2017). In the context of our study, ambidexterity means that university research groups must be able to develop capabilities and incorporate processes that foster and improve activities related to exploitation of knowledge, while simultaneously creating new knowledge - exploration (Sengupta \& Ray, 2017). IA in university research groups is thus understood as the generation of new knowledge of a pioneering character in the scholarly community, through its main products, which can take forms such as articles, books, patents, consulting or training of personnel (García-Aracil et al., 2006; De Saá-Pérez et al., 2017), new methodologies, techniques and technologies. In addition to the generation of new knowledge involved in revolutionary research in cutting-edge fields, one must regularly implement small adaptations of existing studies and research processes, and introduce improvements in the technologies and methods used in research processes to ensure that exploratory and exploitative innovations coexist and enable these processes to reap the benefits of IA.

KT can be a good dynamizer for IA. Innovation is nourished by application of new knowledge, and application of new knowledge leads to change and innovation (Jensen et al., 2007; Lin et al., 2013). Yet the relationship between KT and IA has received little analysis in the literature, despite the studies by Mom et al. (2007), Lin et al. (2013) and Cegarra-Navarro et al. (2019). We find no studies that analyse this relationship in the context adopted here- university research groups.

$\mathrm{KT}$ is crucial for IA because it enables distribution of and access to knowledge of the group's members (Fu et al., 2018), a key aspect of individual and group learning that facilitates IA. Among university research groups, knowledge and its transfer are crucial for creating value and encouraging IA (Sengupta \& Ray, 2017). The exploratory and exploitative innovation activities 
that university research groups develop can be performed independently, but they can also be connected (Chang \& Hughes, 2012). These groups must maintain high levels of competitiveness, measured by the constant development of new studies in addition to existing ones. Since this context is increasingly competitive and complex in higher education, KT and IA are becoming increasingly essential capabilities for universities (Sengupta \& Ray, 2017). Further, university research groups have the function of contributing scholarly results to the socioeconomic development of regions and countries (Observatorio IUNE, 2016). One way to achieve this function is through the IA supported by knowledge management processes. We must recognize that knowledge alone does not encourage achievement of IA; it is necessary to connect this knowledge to other processes, such as knowledge management processes, to transform knowledge into innovations (Eisenhardt \& Martin, 2000). We therefore propose:

$H 3: \mathrm{KT}$ is positively related to IA in public university research groups.

$\mathrm{KA}$ is a crucial issue for developing innovations (Cabello-Medina et al., 2011; Wehn \& Montalvo, 2018) in the context of our study. Analysing the effects of KA on IA, Jansen et al., (2005) and Limaj and Bernroider (2017) find a relationship between the variables but conclude that there is still much to be learned about the effect of different practices and the study context. The research on KA in Swift (2016) has helped to clarify the capabilities needed both to explore and to exploit. Greater KA contributes to variety of knowledge and enhances both creativity and the ability to implement new ideas, fostering rapid IA (Solís-Molina et al., 2018). In other words, simultaneous pursuit of exploratory and exploitative innovations requires prior development of knowledge, and thus development of KA within public university research groups (Gurtner \& Reinhardt, 2016). What is more, it is crucial for public university research groups to help strengthen KA, enabling generation of exploration and exploitation processes within them, resulting in improved performance (Lucena \& Roper, 2016). 
IA thus, depends on creation of the right preconditions—-such as KA (Bierly et al., 2009). KA conditions how well university research groups can use new knowledge and reconfigure their knowledge base to achieve outcomes (Cohen \& Levinthal, 1990; McAdam et al., 2010), i.e., IA. Good KA enables university research groups to acquire, assimilate, transform and apply knowledge effectively (Lane et al., 2006), encouraging the research process through simultaneous search for exploitation and exploration. Although the knowledge acquisition process begins as an individual activity (Kim, 1993), developing innovations usually requires groups of individuals (Edmondson \& Nembhard, 2009). It is therefore important to find practices that facilitate the application of acquired knowledge (Teece \& Pisano, 1994). Since university research groups have their own KA routines, they can manage the resulting cognitive load better (Fernhaber \& Patel, 2012) and use it in IA. We also believe that the quality of the members of public university research groups facilitates assimilation of knowledge within the group, as well as its combination and recombination, which in turn are useful for KA (Lucena \& Roper, 2016), thus facilitating IA (Limaj \& Bernroider, 2017). Based on the foregoing, we believe that public university research groups have intrinsically high levels of KA because they employ people with highly specialized knowledge (McAdam et al., 2010), which encourages development of IA (Solís-Molina et al., 2018) and improves scholarly performance. Therefore:

H4: KA is positively related to IA in public university research groups.

\subsection{The mediating role of knowledge transfer and knowledge absorptive capacity}

The relationships developed above lead us to formulate our hypotheses on the mediating role of KT and KA in the relationship between internal networking and IA. One might initially 
expect a direct relationship between internal networking and IA. Some studies demonstrate this relationship (Lin \& McDonough, 2011; Radomska et al., 2019; Agostini et al., 2017). Since internal networking inherently drives innovation activities and contributes to obtaining high levels of exploration and exploitation (Lin \& McDonough, 2011), internal networking seems necessary to value creation in innovation processes (Waychal et al., 2011). This relationship need not always be direct, however. It can be affected by other internal factors, which leads us to open scholarly debate. Our analysis leads us to conclude that the relationship between internal networking and IA in university research groups is not as simple as it seems (in direct relationships, only one relationship is considered (Cao et al., 2009) and that other (mediating) variables complicate this relationship. We ground our thinking in the interaction that occurs when internal networking is nurtured, fostering interactions that impact relational coordination among researchers to encourage simultaneous development of exploratory and exploitative innovations (Wang et al., 2006) through KT and KA processes (Wang et al., 2006).

The mediating effect of KT can thus come to negate the direct relationship between internal networking and IA, providing a better explanation of the variable through mediation. Although internal networking enables better communication and coordination, and fosters closer connections among researchers (Ming-Chao et al., 2018; Cabeza et al., 2018; García-Sanchez et al., 2019), these elements alone are not sufficient to develop IA. On the contrary, IA requires that the research group members deliver their knowledge to other researchers for modification and reuse (Chen \& Hung, 2010). It is not enough for the members of the group to have valuable and varied knowledge. They must also share the knowledge to create new knowledge (Lewis et al., 2005). When the knowledge that the group members possess is transferred among them, synergies occur (Liu et al., 2011), as does integration of ideas. Since researchers are knowledge workers (Harvey et al., 2002), KT plays a key role in the context of our study. We thus predict that internal networking within a research group will be more effective when KT exists within 
this group, mediating the relationship to IA. That is, connectivity ensures that internal networking is related to IA if and only if KT is present as a mediating variable. We argue for a mediating effect that increases the probability that the members of university research groups will develop a mental schema that is more committed to effective exploitation and exploration of research opportunities, and ultimately to IA (Fu et al., 2018).

$\mathrm{KA}$, in turn, can better explain IA through its mediating effect, enabling increase in the generation of innovative ideas (Fleming \& Sorenson, 2001) when the new knowledge acquired is recombined with existing knowledge in the research group. We start from the idea that university research groups possess both the abilities needed to use the new knowledge acquired and the technical competencies needed to absorb new knowledge. Further, IA requires researchers to absorb knowledge in order to reconfigure the existing knowledge base (Cohen \& Levinthal, 1990; Bierly et al., 2009). Therefore, university research groups, in which members work together on internal networking to perform common tasks, develop IA if and only if they overcome challenges related to absorption and integration of knowledge (Liao et al., 2015; Majchrzak et al., 2012).

As a whole, internal networking is an important resource that fosters a close social relationship and frequent communication but is not sufficient to achieve IA in the absence of KT and KA. In the specific case of university research groups, conceptualized as communities that practice creative knowledge, KT and KA become an essential mediator between internal networking and IA (see Figure 1). Based on the foregoing, we propose the following hypotheses:

H5: KT mediates the relationship between internal networking and IA.

H6: KA mediates the relationship between internal networking and IA.

Figure 1 summarizes the conceptual framework proposed.

Insert Figure 1. 


\section{Research methodology}

\subsection{Data collection and sampling}

The data were collected from March to May 2010 by distributing questionnaires to Spanish public university research groups. We collected data from groups in all disciplines, as there are no disciplinary differences in the way these groups are organized, managed and run. We chose this sample as the unit of analysis for two main reasons. First, it is important to study the groups' internal processes (Minguillo \& Thelwall, 2015) because these groups have acquired a crucial role in universities as sources of knowledge generation through research (Bayona et al., 2002). Second, these groups are currently considered as one of the basic pillars of university prestige (Minguillo \& Thelwall, 2015) in international rankings.

To test the relationships among the constructs, 3000 Spanish public university research groups were selected through simple random sampling. We contacted the director of each group, as the director plays an important role in the group and holds the highest position in the group's hierarchy (Peltokorpi, 2014). A pre-test with five group directors enabled us to correct errors that affected comprehension of some items and control variables. The directors were affiliated with different universities in Spain (Universidad de Sevilla, Universidad de Extremadura, Universidad de las Palmas, Universidad de Granada and Universidad de Cantabria) and different disciplines (Social Sciences, Experimental Sciences, Humanities, Health Sciences and Technology). Table 1 displays the complete list of universities surveyed.

\section{Insert Table 1 about here}

Spanish university research takes the form of research groups in different areas and of different sizes, composed of university professors and research assistants. These groups are directed by university professors who know the groups' functioning, members and composition because they have been working together for some time. The research groups belonged to all areas of 
knowledge and were surveyed independently of their size, region, age group and disciplinary area (see Table 1).

We obtained 249 valid questionnaires, giving a response rate of $8.3 \%$. As the response rate was relatively low, we tested for nonresponse bias through an ANOVA and found no statistically significant differences between respondents and non-respondents in terms of demographic variables. It is important to consider that surveys addressed only to the directors generally produce much lower response rates (Gielnik et al., 2012; Zacher \& Rosing, 2015).

Groups in the sample generally had 5-10 researchers, representing 50\% of the total, while 37\% of the groups had over 10 researchers, and only $13 \%$ had fewer than 5. Significantly, Johnston (1994) affirms that the minimum group size for a group to compete internationally is 4-6 members.

If we compare the descriptive characteristics of the sample to those of prior studies that analyse the same unit, we find that research groups in Spanish universities must have at least three members, at least one of whom must be a civil servant, as must the group's director (De SaáPérez et al., 2017). The distribution of the sample by area is similar to other studies performed with Spanish university research groups (De Saá-Pérez et al., 2017; García-Sánchez et al., 2017). Providing that the sample analysed fulfils all of the above-mentioned conditions, we assume that it is representative of the population.

\subsection{Measures}

Table 2 presents all scales and the items from each that were used in this research and its descriptive statistics.

\section{Insert Table 2 about here}




\section{Data analysis and results}

\subsection{Confirmatory factor analyses and measurement model}

We validated the measurement model using ML estimation included in the EQS 6.2 software. The validation consisted of determining whether the factor loadings for each item were significant ( $\mathrm{t}$-value>1.96, $\mathrm{p}<0.05)$ and whether their individual reliability $\left(\mathrm{R}^{2}\right)$ was above the recommended minimum of 0.5 . As all items fulfilled these conditions, we did not have to eliminate any, and we confirmed convergent validity of the scales in our study. Internal consistency was demonstrated by the Cronbach's alpha values (Table 2). We also confirmed that the measurement model fit the data well: normed $\chi^{2}=\chi^{2} /$ degrees of freedom $=627.819 / 242=2.59(<5)$, comparative fit index CFI=0.914 $(<0.9)$, Bollen's fit index $\mathrm{IFI}=0.915(>0.9)$, root mean square error of approximation RMSEA=0.08 $(\leq 0.08)$, adjusted goodness of fit index AGFI=0.8 (>0.5), goodness of fit index GFI=0.835 (>0.5), normed fit index NFI=0.87 (>0.5), non-normed fit index NNFI=0.902 $(>0.5)$. Based on the minimum values required for good fit of the model, the results obtained show satisfactory fit (Byrne, 1998; Mulaik et al., 1989). We verified the scales' composite reliability (CR) and average variance extracted (AVE). For both measurements, the minimum values required are 0.7 and 0.5 , respectively (Nunnally, 1978). Table 2 shows that the scales are within the accepted limits in all cases, indicating that the measurement model is good. We then studied the discriminant validity of the different scales using the square root of the AVE for each construct larger than its correlations with all other constructs, as shown in Table 3 (Fornell \& Larcker, 1981).

\section{Insert Table 3 about here}

\subsection{Common method variance tests}

As explained above, the data were obtained from the same respondents, and all four constructs used subjective measures. As a possibility of common method bias exists, we conducted 
Harman's single factor test, which is widely used in the literature (Podsakoff et al., 2003). We loaded all variables in the exploratory factor analysis, constraining the number of factors to 1 . As the first component accounts for less than $50 \%$ of all variables, common method variance is not a serious problem in our sample. We also performed exploratory factor analysis for the firstorder level of constructs, which revealed four first-order factors with eigenvalues $>1.0$ accounting for $72.641 \%$ of the variance. Since a single factor did not emerge and the first factor did not account for the majority of the variance, we reach the same conclusion here as in the previous test. The results of these tests confirm the absence of problems related to common method variance.

\subsection{Hypothesis testing}

After performing the scale validation process, we estimated the model proposed, using structural equations modelling (SEM). We chose Covariance-Based SEM with EQS 6.2 because it made structural modelling simpler by providing different ways to create models. The software package also has unique capability for handling non-normal variables, computing multivariate Lagrange multiplier and Wald tests, and estimating reliability of the measurement model (Narayanan, 2012, p. 136).

First, we assessed the fit values of the structural model. We observed the following fit indexes: normed $\chi^{2}=\chi 2 /$ degrees of freedom $=507.281 / 238=2.13(<5), \mathrm{CFI}=0.94(>0.9), \mathrm{IFI}=0.941(>0.9)$, root mean square error of approximation $\mathrm{RMSEA}=0.068(\leq 0.08)$, adjusted goodness of fit index AGFI $=0.823(>0.5)$, goodness of fit index GFI=0.86 $(>0.5)$, normed fit index NFI=0.894 $(>0.5)$ and non-normed fit index NNFI=0.93 (>0.5). Based on the minimum values required for good fit of the model, the results show satisfactory fit (Byrne, 1998; Mulaik et al., 1989). We now examine the results to contrast the hypotheses proposed (see Figure 2). First, the relationship of the variable "Internal Networking" to both "Knowledge Transfer Capacity" and "Knowledge Absorptive Capacity" is positive and significant $(\lambda=0.40, \mathrm{t}$-value $=5.862 ; \lambda=0.404$, t- 
value $=5.765$, respectively). As both coefficients are positive and the t-values are higher than 1.96, we can confirm their significance at a 95\% confidence level. We thus accept Hypotheses $\mathrm{H} 1$ and H2. Second, the result for the relationship between "Knowledge Transfer" and "Innovation Ambidexterity" is not significant $(\lambda=-0.049$, $\mathrm{t}$-value $=0.072)$, leading us to reject Hypothesis H3. Finally, the relationship between "Knowledge Absorptive Capacity" and "Innovation Ambidexterity" $(\lambda=0.662, \mathrm{t}$-value $=8.244)$ is positive and significant, enabling acceptance of Hypothesis H4.

The structural model includes control variables: number of members in the group, area of knowledge and income level. The relationships of group size $(\lambda=0.0898, t$-value $=0.8445)$ and area of knowledge $(\lambda=-0.160, t$-value $=-0.3158)$ to IA were not significant, but the relationship between income level and IA was $(\lambda=0.4681$, $\mathrm{t}$-value $=5.8541)$. This result indicates that neither group size nor area of knowledge is related to IA but that groups with more financial resources are more likely to be ambidextrous in innovation.

\subsubsection{Mediation analysis (Hypotheses 5 and 6)}

Since we reject $\mathrm{H} 3$, there is no evidence that internal networking influences IA indirectly via KT, and thus no evidence to support H5. However, the acceptance of H4 led us to try to provide evidence for the possible mediating effect of knowledge absorptive capacity, and thus for H6. To confirm this possibility, we followed Rhee et al. (2010) in performing decomposition of effects, disaggregating the total effect of an independent variable on a dependent variable into its indirect and direct effects (Rhee et al., 2010; Tabachnick \& Fidell, 1996). The presence of a significant indirect effect indicates that a significant part of the relationship between the dependent and independent variable is explained through the mediating variable.

The results for the structural model are reported in Table 4, including the direct and indirect effects for all paths.

\section{Insert Table 4 about here}


Estimation of the indirect effects enabled us to verify H6. The results showed that IA was positively influenced by internal networking through knowledge absorptive capacity $(\lambda=0.259$, $\mathrm{t}=5.027$ ). To analyse the total mediating effect of knowledge absorptive capacity, we examined the direct relationship of the variable "Internal Networking" to IA. The result $(\lambda=-0.038)$ reveals a non-significant relationship, indicating that the relationship of network ties to IA occurs entirely through knowledge absorptive capacity, which exercises a total mediating effect. Additionally, we analysed goodness of fit in the structural model by examining various indices and their minimum recommended values: normed $\chi^{2}=281.316 / 140=2(<5), \mathrm{CFI}=0.958(>0.5)$, $\mathrm{IFI}=0.958(<0.9), \mathrm{RMSEA}=0.064(\leq 0.08), \mathrm{AGFI}=0.859(>0.5), \mathrm{GFI}=0.896(>0.5), \mathrm{NFI}=0.92$ $(>0.5), \mathrm{NNFI}=0.95(>0.5)$. All fit indices obtained exceed the required minimum values mentioned in 4.1 and 4.3. We formulated an alternative model in which knowledge absorptive capacity was an exogenous variable instead of a mediating variable, and the goodness of fit values from the results supported the notion that the initial model had greater exploratory power. To complement this analysis, we used the method proposed by Baron and Kenny (1986) to confirm the existence of mediating effects. All conditions are satisfactorily fulfilled, confirming what the authors call total mediating effect. Moreover, following the recommendation of Preacher and Hayes (2008), we conducted bootstrapping analysis to assess the indirect effects of knowledge absorptive capacity in the Internal Networking-IA relationship. The "PROCESS" package in SPSS was used to investigate the mediation model and obtain bootstrapped confidence intervals (CIs) for each indirect effect. After conducting 10,000 bootstrap replicates, we calculated the effect size of IA as 0.225 with $95 \%$ bias-corrected CIs $[.1271, .3385]$. According to this analysis, the association between network ties and IA is mediated through knowledge absorptive capacity and is significant because the bias-corrected CIs did not include zero. 


\section{Insert Figure 2}

\section{Discussion}

In an increasingly competitive university context, this article has attempted to deepen knowledge of the issues (internal networking and knowledge management processes) that improve achievement of ambidextrous innovative performance. In this context, the study's goal has been to examine whether KT and KA mediate the relationship between internal networking and IA in university research groups. First, the study results show a positive and significant relationship of the variable internal networking to KT and KA, supporting Hypotheses $\mathrm{H} 1$ and H2. Both hypotheses seem intuitive because the literature has described the relationship among these variables extensively. It is interesting to test these hypotheses, however, because prior studies have generally been performed on private organizations and have analysed external networks. Our study responds to the literature's call to investigate the relationship of internal networking to $\mathrm{KT}$ and $\mathrm{KA}$, which has received little attention for the case of public organizations (Oluikpe, 2012; Ringel-Bickelmaier \& Ringel, 2010; Al Ahbabi et al., 2019). Our results support and complement the only study found, García-Sanchez et al. (2019). Whereas García-Sánchez et al. (2019) analyse the influence of internal networking on the quality of relationships and knowledge sharing in academic research groups, our results show that internal networking contributes to the integration and creation of stronger links among researchers in university research groups, and to greater cohesion and commitment, which in turn increase not only KT but also KA in these groups (Stvilia et al., 2011; García-Sanchez et al., 2019). That is, the presence of internal networking in university research groups is important because it encourages transfer and absorption of new knowledge by improving the quality of the relationships established (Pezzoni et al., 2012). We also proposed that knowledge management 
in university research helps to overcome difficulties due to the university culture of working alone, which does not foster cooperation and exchange.

On the other hand, the KA literature generally addresses external KA in its relationship to cooperation in external networks (Cross \& Cummings, 2004; Cohen \& Levinthal, 1990; Lowik et al., 2016). The positive relationship between internal networking and KA (H2) provides information on KA as an internal capability, in response to the literature's identification of a need to continue deepening the study of dynamic capabilities in organizations (Barrales-Molina et al., 2013). Our results thus help to reduce the discrepancies between theory and practice on the nature of KA and its relationship to internal processes (Cordero \& Ferreira, 2019).

Second, we analysed the relationship between KT and IA (H3). The results for $\mathrm{H} 3$ are not consistent with the few studies we found in the literature. Considering that we did not find a relationship among the variables in our context, we believe that this finding could occur because merely performing KT in university research groups does not necessarily generate IA. In the academic context, researchers have individual interests, a priori, that can reduce efforts to achieve the group's goals (García-Sanchez et al., 2019), in this case, IA. Thus, only part of the knowledge considered as advantageous may be transferred, according to the researcher's particular interests. To enable more extensive KT, we must attend to the structuring of knowledge and its transfer within the group in order to reduce the organizational obstacles that impede its flow (Bryan \& Joyce, 2005) or transformation into IA. IA requires more than the individual researcher's motivation and knowledge to develop new scholarly research (GarcíaSanchez et al., 2019). This result is especially important given that the scant existing literature finds a positive relationship and has called for more information on the relationship between KT and IA (Mom et al., 2007; Lin et al., 2013; Cegarra-Navarro et al., 2019). We take advantage of this result to analyse $\mathrm{H} 5$, which was rejected and which studied the mediating effect of KT in the relationship between internal networking and IA. In the absence of a relationship between 
KT and IA, it was impossible to obtain a mediating effect of KT. If there are no KT processes to motivate knowledge activities that foster exploratory and exploitative innovation results $(\mathrm{Fu}$ et al., 2018), there is no effectiveness in stimulating IA. The variable KT thus cannot mediate the proposed relationship. The underlying reasons for this result may be that the mere existence of KT within the internal network of university research groups is not the condition sine qua non for achieving IA. It may be that the quid of what leads to IA is not the mere fact of knowledge transfer but the way knowledge is transferred in the groups — which, in turn, depends on the type of knowledge, the working mechanisms established for transferring it and the abilities of the group to manage the knowledge, among others.

The relationship between KA and IA is positive and significant, however, permitting acceptance of H4. Studying the effects of KA on IA, Jansen et al., (2005) and Limaj \& Bernroider (2017) conclude that, although they find a relationship between the variables, there is still much to be learned about them and more in-depth research is needed on the study context. Our study responds to these calls by contributing to development of this literature in a specific context. It is worth mentioning that one main reason for this result is that the KA that occurs in research groups enables their members to recombine knowledge for their knowledge creation process (Messeni \& Rotolo, 2013). The feedback and synergies enable KA among the group's members, permitting development of the skills needed to encourage IA and to acquire sufficient internal knowledge for its application, positively impacting IA (Solís-Molina et al., 2018).

The results enable us to demonstrate H6, that is, the total mediating effect of KA in the relationship between internal networking and IA. This means that IA can develop in university research groups if and only if KA is present (Liao et al., 2015). This finding occurs because KA reduces the barriers that can arise among members of university research groups when assimilating and transforming knowledge (Zahra \& George, 2002), enabling them to increase generation of innovative ideas (Fleming \& Sorenson, 2001) through recombination of 
knowledge, encouraging IA. University research groups operate through KA and the professional interactions that occur in their daily research work. The experiences obtained within the group generate new knowledge, which leads to the search for exploratory and exploitative activities, simultaneously encouraging IA as long as the group works on internal networking. The organizational learning and knowledge creation processes are affected by internal contexts — in this case, internal networking — which influences the learning process (Fu et al., 2018) and provides knowledge assets and motivates knowledge-related activities that foster exploratory and exploitative innovation results (Pee \& Lee, 2015; Fu et al., 2018).

There is no single recipe for ensuring implementation of IA in all organizations and promising successful results. Rather, the literature proposes adaptions (Krogstrup \& Brix, 2019) according to context (O'Reilly \& Tushman, 2013; Brix, 2019). In our case, the capability of university research groups to create internal networking among their researchers supported by KA will translate into simultaneous development of incremental and radical innovations.

This finding constitutes the main contribution of our study. In the specific case of university research groups, as communities that practice creative knowledge (García-Sanchez et al., 2019), KA becomes an essential mediator between internal networking and IA to achieve excellent research performance.

\section{Conclusions and theoretical and practical implications}

Our findings contribute to resolving the debate over knowledge management processes in public organizations. First, they show that internal networking too can create conditions favourable for KT and KA in public university research groups. Second, in the context of our study, we find discrepancies between our results and the literature's findings for private organizations concerning the relationship between KT and IA. In our context, the study shows no relationship among the variables, but KA does improve IA in the context analysed. Third and last, our main finding and conclusion is that university research groups can develop IA as 
an element of competitiveness. To do so, the internal networking created in these groups must be supported by KA within the group to achieve IA. Since nearly all of the university's scholarly community is organized into research groups (Ramos-Vielba et al., 2010) to perform research, this finding facilitates achievement of IA within these groups and clarifies the role that knowledge management processes play in this achievement.

From the theoretical perspective, this study contributes to analysing knowledge management and provides specific empirical information to achieve IA in the context of university research groups to fill a gap in the literature. To the best of our knowledge, no empirical studies have analysed the model proposed in university research environments. Our study thus contributes directly to the call in the literature to increase research on public organizations.

The main contribution of this study is that it is the first to provide empirical evidence of the role performed by the combination of internal networking and IA mediated by KA in university research groups. That is, university research groups will not be effective in producing exploratory and exploitative innovations if the internal networking that occurs within them does not have KA.

From the practical point of view, the model helps university research groups that wish to strengthen their activities to achieve IA. The results provide a working instrument for directors and researchers in the group, as they provide support for designing research policies that promote knowledge management practices. We demonstrate the importance of developing universities that support achievement of IA through the use of their main asset, knowledge (González-Brambila, 2014). What is more, this study orients public universities to overcome the competitive pressures that surround them (Kim \& Bak, 2016) and improve their position year by year in university rankings. 


\subsection{Limitations and suggestions for future research}

First, it would be interesting to study other antecedents that facilitate KT and KA in research groups, as well as their possible effects on groups' IA. Observing group behaviour by scholarly area would be interesting, as would studying other geographic areas. Since innovation is the main result of these groups, advances along these lines would be a positive development.

Second, longitudinal study would have been interesting to better understand the relationships analysed in the long term. Third, we examined the criterion of the group's director only; it would be interesting to survey all members directly.

Fourth, developing a culture of IA within the group and encouraging proper, healthy networking that motivates knowledge management processes is very important. This interesting line of research could incorporate management of emotional intelligence into management of research groups and their leaders. Prior studies show that these issues are determining factors for good networking and have positive effects on knowledge management processes in project-related research processes (Decker et al., 2009).

\section{References}

Agostini, L., Nosella, A. \& Filippini, R. (2017). Ambidextrous organization and knowledge exploration and exploitation: The mediating role of internal networking. International Journal of Business Innovation and Research, 14(1), 122-138.

Al Ahbabi, S.A., Singh, S.K., Balasubramanian, S., \& Gaur, S.S. (2019). Employee perception of impact of knowledge management processes on public sector performance. Journal of Knowledge Management, 23, 351-373.

Arbussà, A., \& Coenders, G. (2007). Innovation activities, use of appropriation instruments and absorptive capacity: Evidence from Spanish firms. Research Policy, 36, 1545-1558.

Argote L., \& Ingram P. (2000). Knowledge transfer: A basis for competitive advantage in firms. Organizational Behavior and Human Decision Processes, 82(1), 150-169. DOI: http://dx.doi.org/10.1006/obhd.2000.2893. 
Armbrecht, F.M.R., Chapas, R.B., Chappelow, C.C., Farris, G.F., Friga, P.N., Hartz, C.A., McIlvaine, M.E., Postle, S.R., \& Whitwell, G.E. (2001). Knowledge Management in Research and Development. Research-Technology Management, 44(4), 28-48.

Baggio, R., \& Cooper, C. (2010). Knowledge transfer in a tourism destination: The effects of a network structure. The Service Industries Journal, 30(10), 17571771, DOI: 10.1080/02642060903580649.

Baron, R.M., \& Kenny, D.A. (1986). The moderator-mediator variable distinction in social psychological research: Conceptual, strategic, and statistical considerations. Journal of Personality and Social Psychology, 51, 1173-1182.

Barrales-Molina, V., Bustinza, O. F., \& Gutiérrez-Gutiérrez, L. J. (2013). Explaining the causes and effects of Dynamic Capabilities generation - A Multiple-Indicator Multiple-Cause modelling approach. British Journal of Management, 24, 571-591. DOI: 10.1111/j.14678551.2012.00829.x

Bayona, C., García, M.T., \& Huerta, E. (2002). Collaboration in R\&D with universities and research centres: An empirical study of Spanish firms, $R \& D$ Management, 32(4), 321-341.

Bhatt, G.D. (2001). Knowledge management in organizations: Examining the interaction between technologies, techniques, and people. Journal of Knowledge Management, 5(1), 6875.

Bierly P.E., Damanpour F., \& Santoro M.D. (2009). The application of external knowledge: organizational conditions for exploration and exploitation. Journal of Management Studies, 46(3), 481-509.

Block, M. (2013). Intra-organisational knowledge sharing: A holistic approach to the management of knowledge, Europaeischer Hochschulverlag, Bremen.

Bock, G.W., Zmud, R.W., \& Kim, Y.G. (2005). Behavioral intention formation in knowledge sharing: examining the roles of extrinsic motivators, social psychological forces, and organizational climate. MIS Quarterly, 29(1), 87-111.

Brix, J. (2019). Innovation capacity building: an approach to maintaining balance between exploration and exploitation in organizational Learning. The Learning Organization, 26(1), $12-$ 26.

Bryan, L., \& Joyce, C. (2005). The 21st century organization. The McKinsey Quarterly, 3, 2129

Byrne, D. (1998). Complexity theory and the social sciences: An introduction. London and New York: Routledge. 
Cabello-Medina, C., López-Cabrales, Á., \& Valle-Cabrera, R. (2011). Leveraging the innovative performance of human capital through HRM and social capital in Spanish firms. The International Journal of Human Resource Management, 22(4), 807-828.

Cabeza, P.D., Llorens, M.F.J., \& Gutierrez, G.L. (2017). Network ties and transactive memory systems: Leadership as an enabler. Leadership \& Organization Development Journal, 38(1), 56-73. DOI 10.1108/LODJ-11-2015-0247.

Cabeza-Pullés D., Gutierrez-Gutierrez, L.J., \& Llorens-Montes, F.J. (2018). Drivers for performance in innovative research groups: The mediating role of transactive memory system. BRQ Business Research Quarterly, 21(3), 180-194.

Cao, Q., Gedajlovic, E., \& Zhang, H. (2009). Unpacking organizational ambidexterity: dimensions, contingencies, and synergistic effects. Organization Science, 20(4), 781-796. DOI. org /10.1287/orsc. 1090.0426 .

Cegarra-Navarro, J.G., Jiménez-Jiménez, D., \& Garcia-Perez, A. (2019). An integrative view of knowledge processes and a learning culture for ambidexterity: Towards improved organisational performance in the banking sector. IEEE Transactions on Engineering Management, (In-press), pp. (In-press). https://dx.doi.org/10.1109/TEM.2019.2917430

Chang, Y.Y., \& Hughes, M. (2012). Drivers of innovation ambidexterity in small-to mediumsized firms. European Management Journal, 30, 1-17.

Chen, C.J., \& Hung, S.W. (2010). To give or to receive? Factors influencing members' knowledge sharing and community promotion in professional virtual communities. Information \& Management, 47(4), 226-236.

Chen, W., Rainie, L., \& Wellman, B. (2012). Networked work, in Rainie, H. and Wellman, B. (Eds), Networked: The new social operating system. Cambridge: MIT Press, pp. 171-196.

Chiu, CH.M., Hsu, M.H., \& Wang, E.T.G. (2006). Understanding knowledge sharing in virtual communities: An integration of social capital and social cognitive theories. Decision Support Systems, 42(3), 1872-1888.

Cohen W.M., \& Levinthal, D.A. (1990) Absorptive capacity: A new perspective on learning and innovation. Admin. Sci. $Q, 35(1), 128-152$.

Cordero, P.L., \& Ferreira, J.J. (2019). Absorptive capacity and organizational mechanisms: A systematic review and future directions. Review of International Business and Strategy, 29(1), 61-82.

Cross, R., \& Cummings, J. (2004). Tie and Networks Correlates of Individual Performance in Knowledge-Intensive Work. Academy of Management Journal, 47, 928-937. 
De Saá-Pérez, P., Díaz-Díaz, N.L., Aguiar-Díaz, I., \& Ballesteros-Rodríguez, J.L. (2017). How diversity contributes to academic research teams' performance. $R \& D$ Management, $47(2), 165$ 179.

Decker, B., Landaeta, R.E., \& Kotnour, T.G. (2009). Exploring the relationships between emotional intelligence and the use of knowledge transfer methods in the project environment. Knowledge Management Research and Practice, 7(1), 15-36.

Dimitrova, D., Gruzd, A., Mok, D., Hayat, Z., Mo, G. Y., Wellman, B., \& Zhuo, X. (2013). NAVEL: Studying a networked organization. In E. Kranakis (Ed.), Advances in network analysis and its applications. Berlin: Springer.

Dyer, J.H., \& Hatch, N.W. (2006). Relation-specific capabilities and barriers to knowledge transfers: Creating advantage through network relationships. Strategic Management Journal, 27(8), 701-719.

Ebers, M., \& I. Maurer. (2014). Connections count: How relational embeddedness and relational empowerment foster absorptive capacity. Research Policy, 43(2), 318-332. DOI:10.1016/j. respol.2013.10.017.

Edmondson, A.C., \& Nembhard, I.M. (2009). Product development and learning in project teams: The challenges are the benefits. Journal of Product Innovation Management, 26, 123138.

Eisenhardt, K.M., \& Martin, J.A. (2000). Dynamic capabilities: what are they?. Strategic Management Journal, 21, 1105-1121.

Enkel, E., \& S. Heil. (2014). Preparing for distant collaboration: Antecedents to potential absorptive capacity in cross-industry innovation. Technovation, 34(4), 242-260.

Enkel, E., Heil, S., Hengstler M., \& Wirth, H. (2017). Exploratory and exploitative innovation: To what extent do the dimensions of individual level absorptive capacity contribute? Technovation, 60(61), 29-38.

Farzin R.M., Safari, K.M., Hesan, M., Khalouei, A. (2014). A survey of Critical Success Factors for Strategic Knowledge Management implementation: applications for Service Sector. Procedia - Social and Behavioral Sciences, 109, 595-599.

Fernhaber, S.A., \& Patel, P. (2012). How do young firms manage product portfolio complexity? The role of absorptive capacity and ambidexterity. Strategic Management Journal, 33, 15161539.

Fleming, L., \& Sorenson, O. (2001). Technology as a complex adaptive system: evidence from patent data. Research Policy, 30, 1019-1039. 
Fornell, C., \& Larcker, D.F. (1981). Evaluating structural equation models with unobservable variables and measurement error. Journal of Marketing Research, 18, pp. 39-50.

Fritsch, M., \& Kauffeld-Monz, M. (2010). The impact of network structure on knowledge transfer: An application of social network analysis in the context of regional innovation networks. Annals of Regional Science, 44, 21-38. DOI:10.1007/s00168-008-0245-8.

Fu, L., Zhiying L., \& Suqin L. (2018). Is distributed leadership a driving factor of innovation ambidexterity? An empirical study with mediating and moderating effects. Leadership \& Organization Development Journal, 39(3), 388-405.

García-Aracil, A., Gutiérrez Gracia, A., \& Pérez-Marín, M. (2006) Analysis of the evaluation process of the research performance: an empirical case. Scientometrics, 67(2), 213-230.

García-Sánchez, P., Díaz-Diaz, N.L., \& De Saa'-Pérez, P. (2019). Social capital and knowledge sharing in academic research teams. International Review of Administrative Sciences, 85(1), 191-207.

Gielnik, M.M., Frese, M., Graf, J.M., \& Kampschulte, A. (2012). Creativity in the opportunity identification process and the moderating effect of diversity of information. Journal of Business Venturing, 27, 559-576.

González-Brambila, C.N. (2014). Social capital in academia. Scientometrics 101, 1609-1625.

Gurtner, S., \& Reinhardt, R. (2016). Ambidextrous idea generation-antecedents and outcomes. Journal of Product Innovation Management, 33, 34-54.

Harvey, J., Pettigrew, A., \& Ferlie, E. (2002). The determinants of research group performance: Towards mode 2?. Journal of Management Studies, 39(6), 747-773.

He, Z.L., \& Wong, P.K. (2004). Exploration vs. exploitation: An empirical test of the ambidexterity hypothesis. Organization Science, 15(4), 481-494.

Heavey, C., \& Simsek, Z. (2014). Distributed cognition in top management teams and organizational ambidexterity: the influence of transactive memory systems. Journal of Management, 71(7), 772-783.

Hentonnen, K., Johanson, J.E., \& Janhonen, M. (2014). Work-team bonding and bridging social networks, team identity and performance effectiveness. Personnel Review, 43(3), 330-349.

Hinnant, C., Stvilia, B., Wu, S., Worrall, A., Burnett, G., Burnett, K., Kazmer, M., \& Marty, P. (2012a). Author team diversity and the impact of scientific publications: Evidence from physics research at a national science lab. Library \& Information Science Research, 34, 249-257.

Holsapple, C.W., \& Joshi, K.D. (2000). An investigation of factors that influence the management of knowledge in organizations. Journal of Strategic Information Systems, 9, 235261. 
Jansen, J.J.P., Van Den Bosch, F.A.J., \& Volberda, H.W. (2006). Exploratory innovation, exploitative innovation, and performance: Effects of organizational antecedents and environmental moderators. Management Science, 52(11), 1661-1174.

Jansen, J.J.P., Van den Bosch, F.A.J., in Volberda, H.W. (2005). Exploratory innovation, exploitative innovation, and ambidexterity: The impact of environmental and organizational antecedents. Schmalenbach Business Review, 57, 351-363.

Johnston R. (1994). Effects of resource concentration on research performance. Higher Education. 28, 25-37.

Ju, T.L., Li, C.Y., \& Lee, T.S. (2006). A Contingency Model for Knowledge Management Capability and Innovation. Industrial Management and Data System, 106(6), 855-877.

Kaplan, S., \& Tripsas, M. (2008). Thinking about technology: Applying a cognitive lens to technical change. Research Policy, 37, 790-805.

Khvatova, T., Block, M., Zhukov, D., \& Lesko, S. (2016). How to measure trust: The percolation model applied to intraorganisational knowledge sharing network. Journal of Knowledge Management, 20(5), 918-935.

Kim, D.H. (1993). The link between Individual and organizational learning. Sloan Management Review, 34, 37-45.

Kim, D.H., \& Bak, H.J. (2016). How do scientists respond to performance-based incentives? Evidence from South Korea. International Public Management Journal, 19(1), 31-52.

Krogstrup, H.K., \& Brix, J. (2019). Co-Produktion i Den Offentlige Sektor: Brugerin volvering I KVAlitetsudvikling, Hans Reitzels Forlag, Copenhagen, ISBN: 9788741265384.

Lane, P.J., Koka, B., \& Pathak, S. (2006). The Reification of Absorptive Capacity: A Critical Review and Rejuvenation of the Construct. Academy of Management Review, 31, 833-863.

Lazzarotti, V., Manzini, R., Nosella, A., \& Pellegrini, L. (2017). Innovation ambidexterity of open firms. The role of internal relational social capital. Technology Analysis \& Strategic Management, 29(1), 105-118. http://dx.doi.org/10.1080/09537325.2016.1210119.

Lewis, K., Lange, D., \& Gillis, L. (2005). Transactive memory systems, learning, and learning transfer. Organization Science, 16(6), 581-598.

Liao, J., O’Brien, A.T., Jimmieson, N.L., \& Lloyd, S. (2015). Predicting transactive memory system in multidisciplinary teams: the interplay between team and professional identities. Journal of Business Research, 68 (5), 965-977.

Limaj, E., \& Bernroider, E. (2019). The roles of absorptive capacity and cultural balance for exploratory and exploitative innovation in SMEs. Journal of Business Research, 94(January), 137-153. 
Lin H.-E., McDonough III E.F, Lin S-J., \& Yeh-Yun C. (2013). Managing the exploitation/exploration paradox: The role of a learning capability and innovation ambidexterity. Journal of Product Innovation Management, 30(2), 262-278.

Lin, H., \& McDonough, III, E.F. (2011). Investigating the Role of Leadership and Organizational Culture in Fostering Innovation Ambidexterity. IEEE Transactions on Engineering Management, 58(3), 497-509.

Liu, Y., Keller, R. T., \& Shih, H. A. (2011). The impact of team-member exchange, differentiation, team commitment, and knowledge sharing on R\&D project team performance. $R \& D$ Management, 41(3), 274-287.

Lowik, S., Kraaijenbrink, J., \& Groen, A.J. (2016). The team absorptive capacity triad: a configurational study on individual, enabling, and motivating factors. Journal of Knowledge Management, 20(5), 1083-1103.

Lucena, A., \& Roper, S. (2016). Absorptive capacity and ambidexterity in R\&D: Linking technology alliance diversity and firm innovation. European Management Review, 13, pp. 159178.

Lungeanu, A., \& Contractor, N.S. (2015). The effects of diversity and network ties on innovations: The emergence of a new scientific field. American Behavioral Scientist, 59(5), 548-564. DOI: 10.1177/0002764214556804

Majchrzak, A., More, P.H.B., \& Faraj, S. (2012). Transcending knowledge differences in crossfunctional teams. Organization Science, 23, 951-970.

McAdam, M., McAdam, R., Galbraith, B., \& Kristel, M. (2010). An exploratory study of Principal Investigator roles in UK University Proof-of-Concept processes: an Absorptive Capacity perspective. $R \& D$ Management, 40(5), 2010.

McAdam, R., \& Reid, R. (2000). A comparison of public and private sector perceptions and use of knowledge management. Journal of European Industrial Training, 24(6), 317-329.

Messeni P.A., \& Rotolo, D. (2013). When does centrality matter? Scientific productivity and the moderating role of research specialization and cross community ties. Journal of Organizational Behavior, 34, 648-670.

Ming-Chao, W. Pei-Chen, Ch., \& Shih-Chieh, F. (2018). A critical view of knowledge networks and innovation performance: The mediation role of firms' knowledge integration capability. Journal of Business Research, 88, 222-233.

Minguillo, D., \& Thelwall, M. (2015). Which are the best innovation support infrastructures for universities? Evidence from R\&D output and commercial activities. Scientometrics, 102(1), 1057-1081. 
Mitchell, J.C. (1973). Networks, norms and institutions in J. Boissevain and J.C. Mitchell (eds.) Network Analysis. The Hague: Mouton.

Mom, T.J., Van Den Bosch, F.A., \& Volberda, H.W. (2007). Investigating managers' exploration and exploitation activities: The influence of top-down, bottom-up, and horizontal knowledge inflows. Journal of Management Studies, 44, 910-931. doi:10.1111/j.14676486.2007.00697.x.

Mulaik, S.A., James, L.R., Van Alstine, J., Bennett, N., Lind, S., \& Stilwell, C.D. (1989). Evaluation of goodness-of-fit indices for structural equation models. Psychological Bulletin, $105,430-444$.

Narayanan, A. (2012). A review of eight software packages for structural equation modelling. The American Statistician, 66(2), 129-138.

Nonaka, I., \& Takeuchi, H. (1995). The Knowledge-Creating Company: How Japanese Companies Create the Dynamics of Innovation, Oxford university press, New York, NY.

Nunnally, J.C. (1978). Psychometric theory (2nd ed.). New York: McGraw-Hill.

Observatorio, IUNE. (2016). Informe IUNE 2016 Actividad Investigadora de la Universidad Española. Spain.

Oluikpe, P. (2012). Developing a corporate knowledge management strategy. Journal of Knowledge Management, 16(6), 862-878.

O'Reilly, C.A., \& Tushman, M.L. (2013). The Organizational ambidexterity: past, present, and future. Academy of Management Perspectives, 27(4), 324-338.

Orlikowski, W.J. (2002). Knowing in practice: Enacting a collective capability in distributed organizing. Organization Science, 13(3), 249-273.

Pee, L.G., \& Lee, J. (2015). Intrinsically motivating employees' online knowledge sharing: understanding the effects of job design. International Journal of Information Management, 35(6), 679-690.

Peltokorpi, V. (2014). Transactive memory system coordination mechanisms in organizations: An exploratory case study. Group \& Organization Management, 39, 444-471.

Pezzoni, M., Sterzi, V., \& Lissoni, F. (2012). Career progress in centralized academic systems: Social capital and institutions in France and Italy. Research Policy, 41(4), 704-719.

Podsakoff, P.M., MacKenzie, S.B., Lee, J.Y., \& Podsakoff, N.P. (2003). Common method biases in behavioral research: A critical review of the literature and recommended remedies. Journal of Applied Psychology, 88(5), 879-903.

Powell, W.W. (1998). Learning from collaboration: Knowledge and networks in the biotechnology and pharmaceutical industries. California Management Review, 40(3), 228-240. 
Preacher, K.J., Hayes, A.F. (2008). Contemporary approaches to assessing mediation in communication research". In A.F. Hayes, M.D. Slater and L.B. Snyder (Eds.), The Sage sourcebook of advanced data analysis methods for communication research (pp. 13-54). Thousand Oaks, CA: Sage.

Radomska, J., Przemysław, W., Sołoducho-Pelc, L., \& Silva, S. (2019). The Impact of Trust on the Approach to Management - A Case Study of Creative Industries. Sustainability, 11(816), 116. DOI:10.3390/su11030816.

Raisch, S., Birkinshaw, J., Probst, G., \& Tushman, M.L. (2009). Organizational ambidexterity: Balancing exploitation and exploration for sustained performance. Organization Science, 20, 685-695.

Ramos-Vielba, I., Fernández-Esquinas, M., \& Espinosa de los Monteros, E. (2010). Measuring university-industry collaboration in a regional innovation system. Scientometrics, 84(3), 649667.

Rhee, J., Taekyung, P., \& Do-Hyung, L. (2010). Drivers of innovativeness and performance for innovative SMEs in South Korea: Mediation of learning orientation. Technovation, 30(1), 6575.

Ringel-Bickelmaier, C., \& Ringel, M. (2010). Knowledge management in international organizations. Journal of Knowledge Management, 14(4), 524-539.

Ryan, J.C., \& Hurley, J. (2007). An empirical examination of the relationship between scientists' work environment and research performance. $R \& D$ Management, 37(4), 345-354.

Sengupta, A., \& Ray, A.S. (2017). University research and knowledge transfer: A dynamic view of ambidexterity in British universities. Research Policy, 46(5), 881-897.

Smith, W.K., \& M.L. Tushman. (2005). Managing Strategic Contradictions: A Top Management Model for Managing Innovation Streams. Organization Science, 16(5), 522-536. DOI:10.1287/orsc. 1050.0134 .

Solís-Molina, M., Hernández-Espallardo, M., \& Rodríguez-Orejuela, A. (2018). Performance implications of organizational ambidexterity versus specialization in exploitation or exploration: The role of absorptive capacity. Journal of Business Research, 91, 181-194.

Stvilia, B., Hinnant, C.C., Schindler, K., Worrall, A., Burnett, G., Burnett, K., Kazmer, M.M., \& Marty, P.F. (2011). Composition of scientific teams and publication productivity at a national science lab. Journal of the American Society for Information Science and Technology, 62, 270283.

Swift T. (2016). The perilous leap between exploration and exploitation. Strategic Management Journal, 37, 1688-1698. 
Szulanski, G. (1996). Exploring internal stickiness: Impediments to the transfer of best practice within the firm. Strategic Management Journal, 17 (Winter), 27-43.

Szulanski, G. (1996). Exploring internal stickiness: impediments to the transfer of best practice within the firm. Strategic Management Journal, 17 (Winter Special Issue), 27-43.

Tabachnick, B. G., \& Fidell, L. S. (1996). Using multivariate statistics (3rd ed.). New York: HarperCollins.

Taylor, A., \& Greve, H. R. (2006). Superman or the fantastic four? Knowledge combination and experience in innovative teams. Academy of Management Journal, 49, 723-740.

Teece, D.J., \& Pisano, G. (1994). The dynamic capabilities of enterprises: An introduction. Industrial and Corporate Change, 3(3), 537-556.

Todorova, G., \& Durisin, G. (2007). Absorptive Capacity: Valuing a Reconceptualization. The Academy of Management Review, 32(3), 774-786.

Wang, J., Peter, H.P., \& Guan, J. (2006). Factors influencing knowledge productivity in German research groups: lessons for developing countries. Journal of Knowledge Management, 10(4), 113-126.

Waychal, P., Moharty, R.P., \& Verma, A. (2011). Leading indicators of innovation as a competence for individuals: An empirical study. Journal of Advances in Management, 8(2), 301-322.

Wehn, U., \& Montalvo, C. (2018). Knowledge transfer dynamics and innovation: Behaviour, interactions and aggregated outcomes. Journal of Cleaner Production, 171, S56 - S68.

Wei-Li, W., \& Yi-Chih, L. (2016). How to make a knowledge-sharing group: A group social capital perspective. Personnel Review, 45(3), 523-538.

Wu, L., Lin, C.Y., Aral, S., \& Brynjolfsson, E. (2009). Value of social network. Paper presented at the Winter Information Systems Conference, Salt Lake City, UT. Retrieved from http://smallblue.research.ibm.com/projects/snvalue.

Zacher, H., \& Rosing, K. (2015). Ambidextrous leadership and team innovation. Leadership \& Organization Development Journal, 36(1), 54-68. DOI: doi.org/10.1108/LODJ-11-2012-0141. Zahra, S., \& George, G. (2002). Absorptive capacity: A review, reconceptualization, and extension. Academy of Management Review, 27(2), 185-203. 


\begin{tabular}{|c|c|c|c|c|c|c|}
\hline \multirow[t]{18}{*}{$\begin{array}{l}\text { Table } 1 \\
\text { Complete }\end{array}$} & Autonomous region & Frequency & Percentage & $\begin{array}{c}\text { Frequency } \\
(3000 \\
\text { groups })\end{array}$ & Percentage & list \\
\hline & Andalusia & 31 & 12.45 & 314 & 10.47 & \\
\hline & Aragon & 13 & 5.22 & 243 & 8.10 & \\
\hline & Canary Islands & 14 & 5.62 & 102 & 3.40 & \\
\hline & Cantabria & 20 & 8.03 & 205 & 6.83 & \\
\hline & Castilla-La Mancha & 18 & 7.23 & 188 & 6.27 & \\
\hline & Catalonia & 17 & 6.83 & 186 & 6.20 & \\
\hline & Community of Madrid & 21 & 8.43 & 210 & 7.00 & \\
\hline & Navarre & 30 & 12.05 & 340 & 11.33 & \\
\hline & Valencia & 12 & 4.82 & 205 & 6.83 & \\
\hline & Estremadura & 14 & 5.62 & 210 & 7.00 & \\
\hline & Galicia & 10 & 4.02 & 196 & 6.53 & \\
\hline & Balearic Islands & 12 & 4.82 & 195 & 6.50 & \\
\hline & Rioja & 6 & 2.41 & 132 & 4.40 & \\
\hline & The Basque Country & 14 & 5.62 & 105 & 3.50 & \\
\hline & Asturias & 11 & 4.41 & 97 & 3.23 & \\
\hline & Murcia & 6 & 2.41 & 72 & 2.40 & \\
\hline & TOTAL & 249 & 100.00 & 3000 & 100.00 & \\
\hline
\end{tabular}

universities surveyed by region and Area of knowledge

\begin{tabular}{|l|c|c|}
\hline & Frequency & Percentage \\
\hline Area of knowledge & & 18.07 \\
\hline Social sciences & 45 & 21.3 \\
\hline Humanities & 53 & 28.9 \\
\hline Experimental sciences & 72 & 7.63 \\
\hline Technology & 19 & 24.1 \\
\hline Health sciences & 60 & 100.00 \\
\hline TOTAL & 249 & \\
\hline
\end{tabular}




\section{Table 2}

Measurement scales and descriptive statistics.

\begin{tabular}{|c|c|c|c|c|c|}
\hline Construct/ Item & Mean & S.D. & CR & AVE & CA \\
\hline Internal Networking (IN) (Adapted from Chiu et al., 2006) & & & 0.901 & 0.7 & 0.875 \\
\hline I maintain a close social relationship with some members of my team. (IN1) & 5.46 & 1.578 & & & \\
\hline I spend a lot of time interacting with some members of the team. (IN2) & 5.44 & 1.482 & & & \\
\hline I know some members of my team on a personal level. (IN3) & 5.95 & 1.355 & & & \\
\hline I communicate frequently with some members of the team. (IN4) & 6.24 & 1.025 & & & \\
\hline Knowledge Transfer (KT) (Adapted from Bock et al., 2005) & & & 0.920 & 0.698 & 0.92 \\
\hline $\begin{array}{l}\text { I can often share my work reports and official documents with other } \\
\text { members of the research team. (KT1) }\end{array}$ & 6.35 & 0.864 & & & \\
\hline $\begin{array}{l}\text { I always offer my manuals, methodologies and models to our research team } \\
\text { members. (KT2) }\end{array}$ & 6.45 & 0.879 & & & \\
\hline $\begin{array}{l}\text { I often share my experience or work knowledge with the members of our } \\
\text { research team. (KT3) }\end{array}$ & 6.49 & 0.823 & & & \\
\hline $\begin{array}{l}\text { I always offer my knowledge or knowledge requested by members of our } \\
\text { research team. (KT4) }\end{array}$ & 6.58 & 0.714 & & & \\
\hline $\begin{array}{l}\text { I try to share experience from my training effectively with the members of } \\
\text { our research team. (KT5) }\end{array}$ & 6.56 & 0.744 & & & \\
\hline Knowledge Absorptive Capacity (KA) (Adapted from Szulanski, 1996) & & & 0.89 & 0.57 & 0.884 \\
\hline $\begin{array}{l}\text { The new knowledge acquired is consistent with the existing knowledge of } \\
\text { the research group. (KA1) }\end{array}$ & 6.01 & 0.991 & & & \\
\hline $\begin{array}{l}\text { The research group has a clear structure of responsibilities and performance } \\
\text { to use the new knowledge acquired. (KA2) }\end{array}$ & 5.36 & 1.328 & & & \\
\hline $\begin{array}{l}\text { The research group has the skills needed to use the new knowledge } \\
\text { acquired. (KA3) }\end{array}$ & 5.95 & .964 & & & \\
\hline $\begin{array}{l}\text { The research group has the technical competencies needed to absorb new } \\
\text { knowledge. (KA4) }\end{array}$ & 5.93 & 1.017 & & & \\
\hline $\begin{array}{l}\text { The research group has the leadership competencies to absorb new } \\
\text { knowledge. (KA5) }\end{array}$ & 5.83 & 1.058 & & & \\
\hline $\begin{array}{l}\text { We know very well who can use the new knowledge acquired in the } \\
\text { research group. (KA6) }\end{array}$ & 6.10 & 0.953 & & & \\
\hline $\begin{array}{l}\text { Innovation Ambidexterity (AMBIDEX) (Adapted from and inspired } \\
\text { by Jansen et al., 2006) }\end{array}$ & & & 0.945 & 0.656 & 0.94 \\
\hline We are innovative in the group's new research. (AMBIDEX1) & 5.859 & 1.177 & & & \\
\hline $\begin{array}{l}\text { Our group accepts new research proposals that go beyond existing ones. } \\
\text { (AMBIDEX2) }\end{array}$ & 5.558 & 1.309 & & & \\
\hline Our speed in developing new research studies is high. (AMBIDEX3) & 4.996 & 1.404 & & & \\
\hline $\begin{array}{l}\text { Our group has introduced a high number of new research studies on the } \\
\text { market. (AMBIDEX4) }\end{array}$ & 4.703 & 1.692 & & & \\
\hline $\begin{array}{l}\text { A high number of our new research studies are pioneering in the scholarly } \\
\text { community. (AMBIDEX5) }\end{array}$ & 4.843 & 1.582 & & & \\
\hline We often refine and update the research studies in the group. (AMBIDEX6) & 5.076 & 1.455 & & & \\
\hline $\begin{array}{l}\text { We regularly implement small adaptations to existing research studies and } \\
\text { processes. (AMBIDEX7) }\end{array}$ & 5.004 & 1.366 & & & \\
\hline $\begin{array}{l}\text { We introduce improvements in the technologies and methods used in our } \\
\text { research processes. (AMBIDEX8) }\end{array}$ & 5.088 & 1.382 & & & \\
\hline $\begin{array}{l}\text { We improve the efficiency of our methodologies, techniques and } \\
\text { technologies. (AMBIDEX9) }\end{array}$ & 4.823 & 1.414 & & & \\
\hline
\end{tabular}

Notes: $\mathrm{CR}=$ composite reliability; $\mathrm{AVE}=$ average variance extracted; $\mathrm{CA}=$ Cronbach's $\alpha$ 
Table 3

Mean, standard deviation and discriminant validity.

\begin{tabular}{|c|c|c|c|c|c|}
\hline Variable & Mean & SD & $\mathbf{1}$ & 2 & 3 \\
\hline Internal Networking & 5.77 & 1.17 & 0.836 & & \\
\hline Knowledge Transfer & 6.49 & 0.70 & $0.392 * * *$ & 0.835 & \\
\hline Knowledge Absorptive Capacity & 5.87 & 0.84 & $0.359 * * *$ & $0.536 * * *$ & 0.754 \\
\hline Innovation Ambidexterity & 5.11 & 1.17 & $0.212 * * *$ & $0.306^{* * *}$ & $0.623 *$ \\
\hline
\end{tabular}

Notes: $* * * \mathrm{p}<0.01$; Diagonal represents the square root of the AVE; below the diagonal represents the correlation matrix.

\section{Table 4}

Results of the structural model, including direct and indirect effects.

\begin{tabular}{|l|l|l|}
\hline Path & $\lambda$ & $\mathrm{t}$-value \\
\hline $\begin{array}{l}\text { Direct effects } \\
\text { Internal Networking } \rightarrow \text { Knowledge Absorptive Capacity }\end{array}$ & 0.392 & 5.628 \\
$\begin{array}{l}\text { Internal Networking } \rightarrow \text { Innovation Ambidexterity } \\
\text { Knowledge Absorptive Capacity } \rightarrow \text { Innovation Ambidexterity }\end{array}$ & -0.038 & -0.677 \\
\hline Indirect effects & 0.66 & 7.861 \\
Internal Networking $\rightarrow$ Knowledge Absorptive Capacity $\rightarrow$ Innovation Ambidexterity & 0.259 & 5.027 \\
\hline Total effects & 0.392 & 5.628 \\
Internal Networking $\rightarrow$ Knowledge Absorptive Capacity & 0.66 & 7.861 \\
Knowledge Absorptive Capacity $\rightarrow$ Innovation Ambidexterity & 0.222 & 3.465 \\
Internal Networking $\rightarrow$ Knowledge Absorptive Capacity $\rightarrow$ Innovation Ambidexterity & & \\
\hline
\end{tabular}




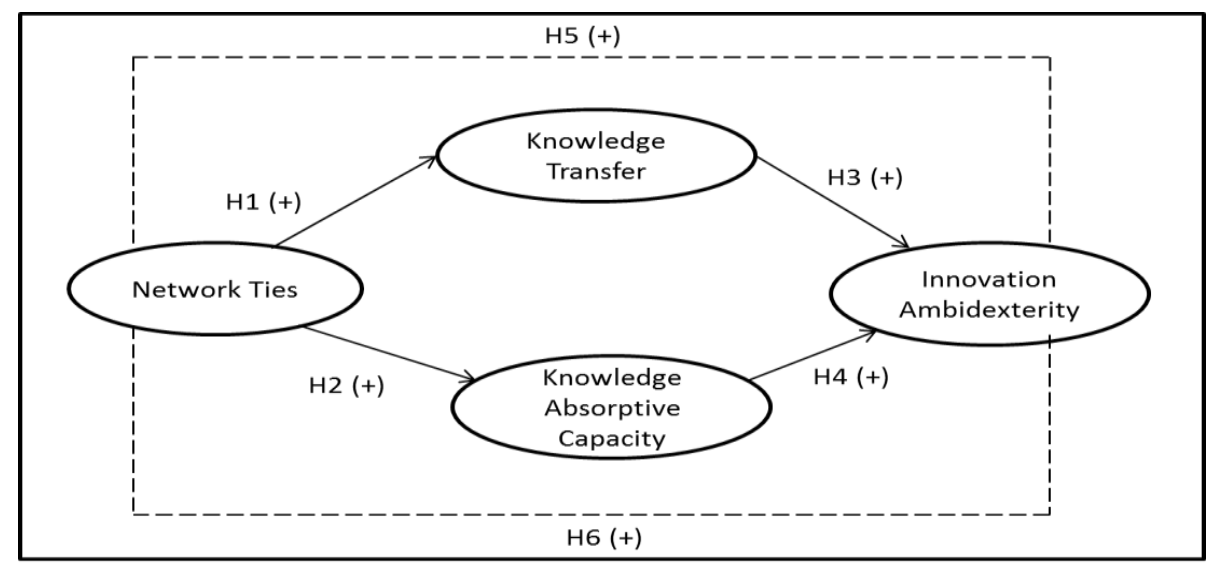

Fig. 1. Hypothesised model

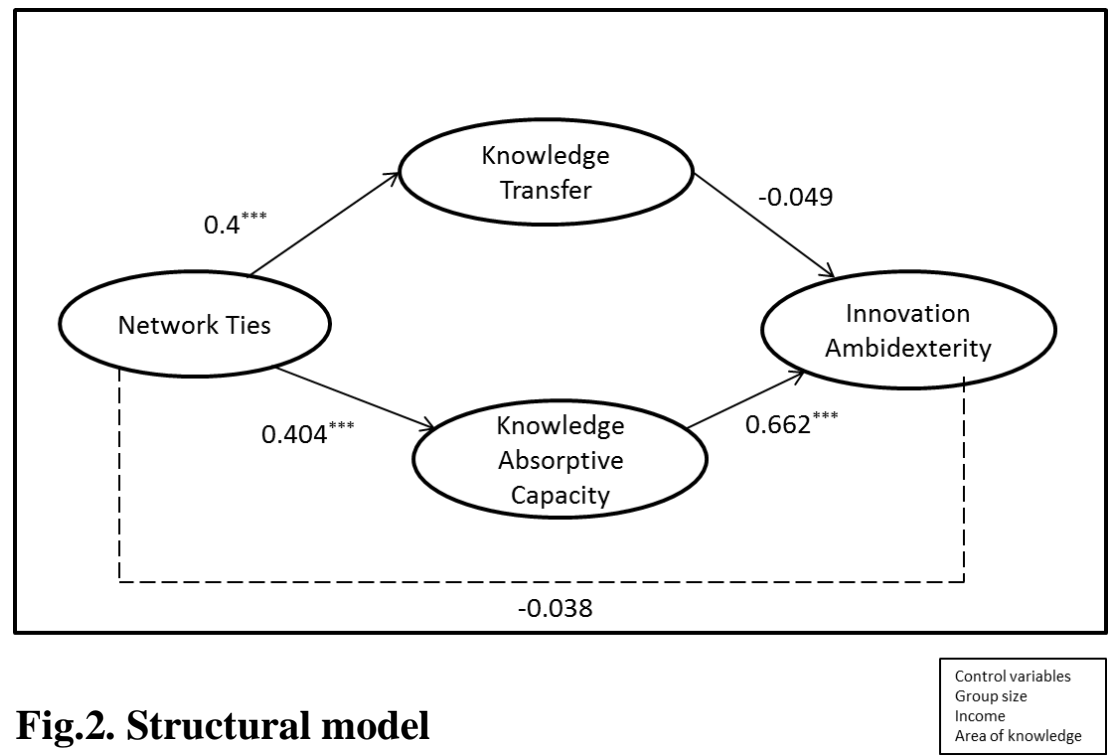

